\title{
The Existence of Culinary at Lomban Festival in Jepara: Comparative Study of The Dutch East Indies and Reformation Period
}

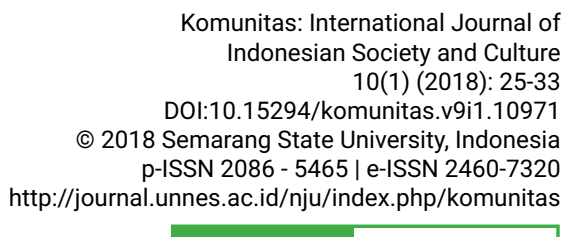

UNNES

JOURNALS

\author{
Sri Indrahti ${ }^{1}$, Yanuar Yoga Prasetyawan², Alamsyah ${ }^{3}$, Siti Maziyah ${ }^{4}$ \\ ${ }^{1}$ Faculty of Humanities Diponegoro University Semarang
}

Received: 3 September 2018; Accepted: 1 March 2018; Published: 30 March 2018

\begin{abstract}
In Jepara, various cultural activities are conducted regularly every year. This cultural activity is always accompanied by a culinary presentation in accordance with the activities, needs, and interests. One of the cultural activities in Jepara is the lomban festival. In this local tradition, a variety of culinary is presented as complement to the cultural activities. The culinary consists of various types, such as market snacks and complete food with rice, vegetables, and side dishes. The culinary in this lomban activity is described in sequence and detail. The culinary depicts the belief, symbolic and spiritual meaning of the supporters of that culture. Through this study, various types of culinary in cultural activities are well described including the symbolic and spiritual meaning behind the culinary presentation.
\end{abstract}

\section{Keywords}

lomban festival; culinary; culture; description; simbolic; Jepara

\section{INTRODUCTION}

Social interaction leaves a trace of tangible and intangible culture (Koentjaraningrat, 2003: 74-75). The cultural results are inherited from generation to generation continuously. Cultural heritage is a non-renewable, finite, and contextual cultural resourches. This cultural resourches are seen as a historical record in the form of artifact, ecofact, sociofact which can strengthen the personal identity of the nation (Atmosudiro, 2004: 2 and 7; Garraghan, 1956:11). The form of culture, whether in the form of objects or not, holds philosophical meaning in the culture (Christomy dan Yuwono, 2004). The cultu- ral resourches are also found in the local level, including Jepara. One cultural heritage which still exists in Jepara today is lomban festival or Syawalan which is often called as sea charity ceremony. This event is held one week after Lebaran day, and it is interpreted as the end of Lebaran (Indrahti and Maziyah, 2006: 37). This event is celebrated in the sea, and people in that society believe that the sea can be used for whole of people from every ethnic so that it shows the harmony of

\footnotetext{
Corresponding author

Jl. Prof. Soedarto, Tembalang, Semarang City

Central Java 50275 Indonesia

Email

indrahti@gmail.com
} 
inter-ethnic (Suliyati, T., Rochwulaningsih, Y., \& Utama, M., 2017: 309). In lomban festival, there are lots of distinctive and unique culinary (Interview with Mrs. Hj. Iskarimah on July 12, 2016). This festival culinary has a local wisdom and gives a positive contribution to the society.

At this time, the lomban activity does not focus on one place, but it spreads to some places. However, the location of lomban ritual is in the same place with the pelarungan attraction which is in Kartini beach and Panjang island (interview with Drs. Suhendro and Fredy Santoso VM, S.H., on July 12, 2016). In the historical context, the lomban party has been done since hundreds of years ago in the Dutch period. In its development, this activity has shifted, but its essence remains the same which is asking for blessing to the Almighty to ask for an abundant sustenance in the future (Interview with $\mathrm{Mr}$. Ahmad Marzuki and Drs. Suhendro on July 12, 2016; Sulistyono, 2005:78).

Lomban tradition is one of the coastal communities' tradition. In the opinion of an anthropologist named Ruth Benedict (in Anwar, 2013: 438), local tradition contains certain values which dominate the developing idea, so it builds and influences the rules of conduct and rules of behavior which form the cultural pattern of society. In lomban festival, there are some activities which must be done by the local community. One of the activities is presenting the special culinary for the local community and presenting complementary ritual or offerings (Interview with Fredy Santoso VM, S.H. on July 12, 2016).

The presentation of culinary in the offering of lomban tradition is actually the way for the community to communicate with the highest power who had influenced their life. Through this particular communication, people can rely on their wiches for positive desires (Sholikhin, 2010: 49). Actually, some efforts to approach themselves through ritual of alms, kenduri, selamatan, and so on are the form of abstract cultural accumulation (Endraswara, 2003:195). Offerings tradition which is the custom of Hindus and Buddhists Javanese people still continues until now, and it is coloring the Javanese people's belief (Soekmono, 1993:1733). The presence of intensive Islam in the 16th century also used local cultural wisdom approach through food as a symbol in Islamic belief (Soeratno, 2005: 8). Some foods are interpreted in accordance with the rules of Islam. For example, nasi tumpeng which has existed in pre-Islamic time. In the Islamic time, this food still existed with the meaning which is adapted to Islamic beliefs (Sholikhin, 2010: 52; Poesponegoro, 1993:191).

Based on the importance of culinary in cultural activity, this article will describe the culinary at lomban festival in Jepara. The presentation of culinary is based on the comparative study of lomban festival which was held in the Dutch East Indies and Indonesia reformation period. Through this comparative study, some culinaries which are presented in lomban festival can be pictured and desribed well. Through this explanation, it can be known which culinary is still survive, which culinary changes, and which culinary develops in its presentation.

\section{RESEARCH METHOD}

This research is an analytical descriptive research. This research uses primary and secondary sources. Primary sources are obtained through observation, archives, and interviews. Observation is applied to photograph various types of culinary presented in lomban festival activities ranging from pre, implementation, and post activities. The observation results are in the documentation form of the culinary types used in the activity. Observation aims to obtain a more complete description of the culinary and document the culinary types. Archive sources used in this research are in the form of archive photos, activities documentation, and news from various media. Interviews are conducted with cultural activities actors to get informations relating to the various types of culinary served in the cultural activities, historical backgrounds, culinary supporters, culinary recipes and the values contained in the culinary. This interview is also 
used to explore technical function, cultural meaning and value, social function, or symbolic meaning of culinary or other phenomena. FGD (Focus Group Discussion) is also conducted to sharpen the data and information gathering.

The secondary sourches are from library research towards relevant sourches. This library research is also an attempt to make comparisons in explaining the same phenomena or phenomena which have similarities with the object of research studies, but both phenomena have different location or time period. In order to reveal the philosophy meaning of culinary which is presented, the research uses hermeneutic approach. The symbolic hermeneutic or interpretation position the work not as an object or fact but as a work. Cultural activity which is seen as a work requires more refined and comprehensive understandings (Palmer, 2003: 7-8; Geertz, 1992: vii). The use of hermeneutic approach is to explore something or hidden meanings behind the phenomenon of a human work. It means that culinary as part of culture can tell a lot about a meaning or value from various versions or approaches. Of course, functions or meanings may change because of the development of time. It means that the function or meaning of a culture can be shifted in accordance with the human interest when culinary as part of culture is still functioned for the purposes of human life.

All data which are collected through the above methods and approaches are classified, linked and accumulated between one to another. The primary source and the library source or secondary source are linked as an interpretation form. All data is then synthesized and reconstructed into writing about culinary in lomban festival.

\section{CULINARY AT LOMBAN FES- TIVAL IN DUTCH EAST INDIES PERIOD}

Tijdschrift voor Nederlandsch-Indië (TNI) (1868) illustrates the activity of lomban festival in Jepara. This activity always mentions about ketupat and lepet as culinary which must exist. The shape of Lepet is long and round like a cylinder, and it is made of glutinous rice mixed with coconut milk and grated coconut, and then it is inserted in young coconut leaves then boiled until cooked. Ketupat contains rice mixed with a little salt. This dough is put in a basket made of young coconut leaves with cube or pyramid shape. After it is ready, the ketupat is cooked by using water until it becomes solid or cooked. The size of this ketupat is as big as a small fist. Ketupat is made in various shapes. Sometimes, the shape is like a mosque (TNI, 1868: 87).

In 1868 , lomban activity is the only post-Eid celebration in the North Coast of Central Java. It means that lomban festival only exists in Jepara, and the other places do not have the similar activity. Before lomban festival begins, Jepara people prepare by decorating a fishing boat which will enliven the event. These boats are made beautifully. The front keel, the back keel, and the poles are decorated with pandan leaves, kenanga, soka and ketupat which are tied together. Next, they hang it with flags or banners made of fabric in various colors, but the green color generally dominates those banners. Human replica dolls (kedawangan) which are made of kedebos (nibung leaf bone) are placed on the keel of the boat. Finally, the boats are still decorated with boreh, a mixture of yellow paint (TNI, 1868: 86-87; Alamsyah: 2013: 20).

Ketupat becomes the special dish at lomban festival. In addition to ketupat, there are also duck eggs and palm trees fruit which is round and green or usually called as kolang-kaling. The tree culinaries (ketupat, duck eggs, and kolang-kaling) are used in throwing precessions. The women have to prepare and serve the important food. The food generally consists of side dishes and serbhet. The participants of lomban festival come from Jepara, Semarang, Juwana and Rembang (Veth, 1882:769; Alamsyah, 2013:20).

Ketupat which has been specially packed by the officials (headman) is used as a gift for the regent. The headmen become 
the regent's escort to the lomban festival place at the arena of throwing games. In this activity, the regent carries twelve umbrellas or bamboo insulation. This vehicle is smeared with lime and sometimes marked with images of tigers, dragons, and fish. The regent with several Europeans, Javanese nobles, and his family sit in a marquee which had been designed as a place to rest and enjoy the festival. The ketupat stock is prepared. Some nobles sit behind the protector or aling-alingan, while the other participants take cover behind round shields. The match starts with thousands of eggs and ketupat thrown into the air. The eggs and ketupat are falling all over the place. The participants who follow this festival run for finding kolang-kaling (TNI, 1868: 87, Alamsyah, 2013: 20).

During the festival, in the morning, everyone takes a bath as the sign of luck. At that time in Jepara, it was a day off for market but there were many fruit, food and beverage stalls near the location of the festival. After having meals, people paid visit to Malay cemetery found in the island, praying then placing flowers and inceses (TNI 1868: 88)

According to Veth, lomban activity is called as lomban festival or bada lomban. In 1882, lomban festivals were once celebrated in other areas. However, the series of the activities were limited to slametan (salvation) or sesaji kupat compared to the festival held in Jepara. Sesaji ketupat contain pounded rice with a little amount of salt wrapped in the hand-sized woven coconut leaves. Ketupat is presented with kolang-kaling (moonshaped palm fruit), and a duck egg.

Lomban festival, aside from being celebratory, also has rituals and offerings. The served culinary as the complement for the festival in 1868 were similar to the culinary in 1882 . The culinary repertoire in this activity was ketupat, duck egg, and kolang-kaling. In the day of the festival, all of the people in Jepara took a bath in the morning and dressed up properly. Then all of them boarded to a kind of sailboat. Gamelan (a set of traditional Javanese musical instrument) was also taken up to the sailboat along with the regent and merchants. Thus the ocean be- came full of sailboats. The participants were all hyping the celebration moving toward Panjang Island. Using these sailboats, the participants were scrambling to snatch ketupat. Kolang-kaling prepared were burned and put on leather and egg. By the release of Chinese fireworks and the shooting of empty gun, the celebratory competition began (Veth: 1882:769; Alamsyah: 2013: 19).

After the festival, in the afternoon they had lunch in Kelor Island. The lunch itself was brought from their home. Sometime they cooked there or just bought meals from the nearby stalls (Veth: 1882:768; Alamsyah: 2013: 20).

The activity then continued with cemetery visit in Panjang and Kelor Island. Flowers and inceses were put down on the cemeteries during the process of the visit. This lomban festival had the participants from all over Jepara that there was no activity in the traditional market at all. In the location where the festival held, the regent with the rich Javanese families, and several Europeans sat in the shaded place and were served various culinary such as ketupat and side dishes (TNI, 1868: 88).

The soldiers prepared to throw off thousands of ketupat, eggs, and green palm fruits to the air. Some people who participated ran around to catch them. While doing the session, there was also a dance performance. This session would end when the regent gave a sign to stop. After everything finished, everyone went back to the sailboat and sailed back to the mainland. The sailing was accompanied with the music from gamelan. After 3 p.m. the whole ceremony was finished. The location was also cleaned until there was no trace that a festival just had been held there (Veth: 1882; Alamsyah: 2013: 21). It can be seen that the society really concerned in maintaining the cleanliness of their environment. There was similarity in case of ceremony rituals and offerings in the festival in 1868 and in $\mathbf{1 8 8 2}$. The culinaries served in both of them was also the same which were ketupat, eggs, and palm fruits (Veth: 1882:769; Alamsyah: 2013: 21). 


\section{LOMBAN FESTIVAL CULINARY IN REFORM ERA}

During the Reform era, in 2013 and 2016 exactly, lomban activity or "lomba-lomban" or "lelumban" also maintained the ritual and complementary dishes. The culinaries were served through several stages which are preparation, execution, and post-lomban (Indrahti et al, 2017: 28-42). In the preparation stage, there was buffalo slaughter. The buffalo was being slaughtered with kupat and lepet laced in its neck. Kupat is a type of rice ball wrapped in young coconut leaves. It is boiled in relatively long time over big fire (interview with $\mathrm{Hj}$. Iskarimah, July $\mathbf{1 2}^{\text {th }}$ 2016). Kupat can be used as the plain rice substitute. Lepet is made of sticky rice mixed with grated coconut and salt also wrapped in coconut leaves (interview with $\mathrm{Hj}$. Iskarimah, July $\left.12^{\text {th }} 2016\right)$.

In the following is the picture of a buffalo before laced with kupat and lepet, and soon to be paraded from Ujungbatu beach to the slaughterhouse:

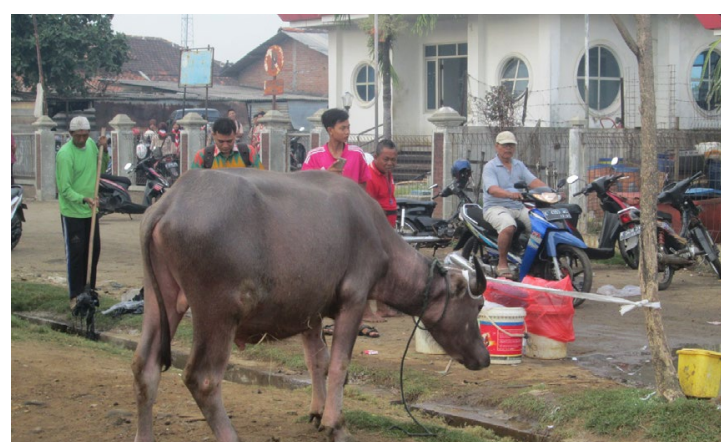

Figure 1. Buffalo before laced with kupat and lepet

(Source: Researcher document, 2016; Indrahti, et al, 2016:28)

In sesaji (offerings) making, various culinary as nasi nuk-nukan, ayam dhekem, grilled chicken, urap with 7 kinds of vegetable, sayur bobor kelor, kupat, lepet, fruits, traditional snacks, sugar, palm sugar, tea, coffee, and other uba rampe (equipment) as sawan laut. Sawan laut is a type of boreh (rub oil) as medicine to help people who are spelled or possessed by haunting sea spirits. Sawan laut consists of various empon-em- pon and mashed flowers using traditional tool. It can be bought from empon-empon seller in the traditional market (interview with $\mathrm{Hj}$. Iskarimah, July $12^{\text {th }}$ 2016).

Here are the pictures depicting the preparation activity in making $u r a b$ with 7 kinds of vegetable and nasi nuk-nukan.

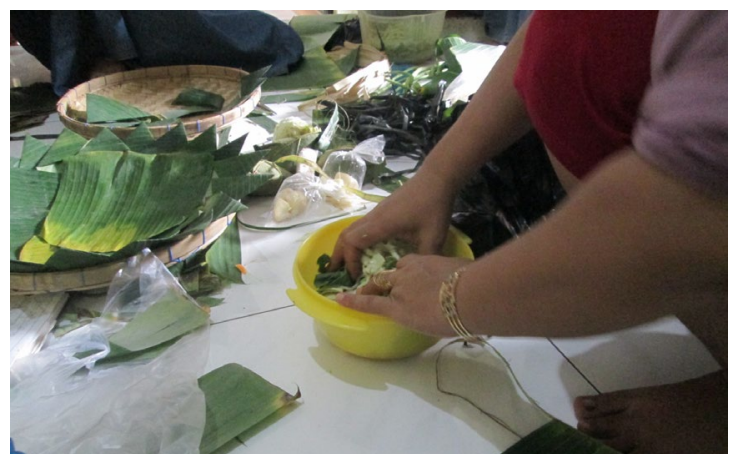

Figure 2. The making of $u r a b$ with seven kinds of vegetables

(Source: Researcher document, 2016)

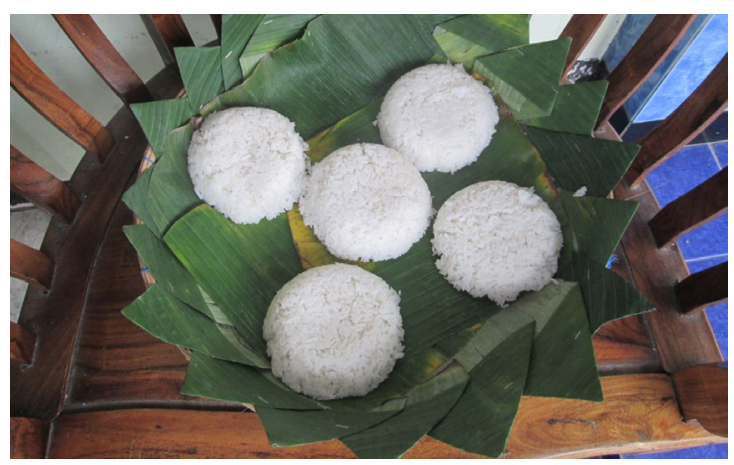

Fogire 3. The making of nasi nuk-nukan. (Source: Researcher document, 2016)

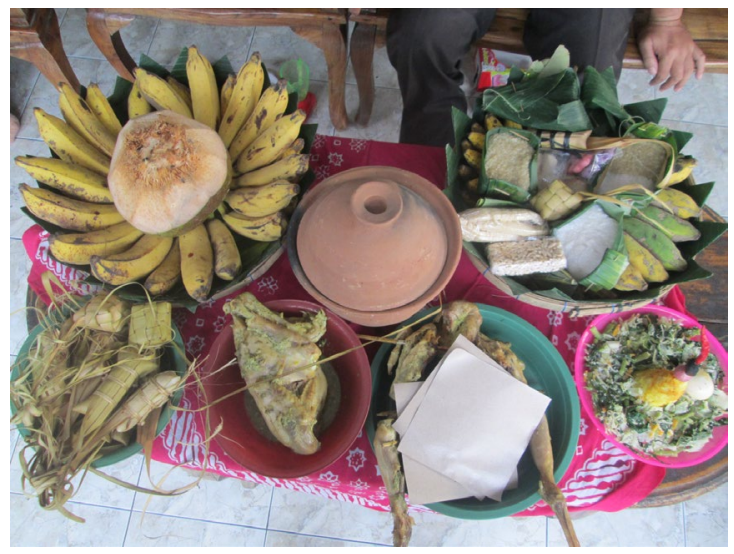

Figure 4. Sample of sesaji (offering)

(Source: Researcher document, 2016). 
Tambir, the place of sesaji, is made of woven bamboo covered by banana leave. In the tip of tambir are decorated with triangular shaped banana leave, as in the following Figure 5.

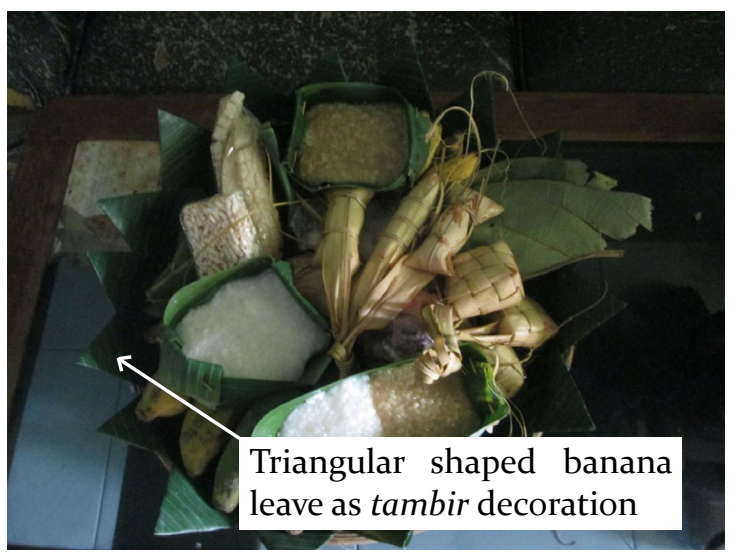

Figure 5. Sesaji basket covered and decorated with banana leave

(Source: Researcher document, 2016)

During the festival, the served culinaries are buffalo head as the offering to be drifted in the sea and other complementaries put on the decorated tambir. The offerings are yellow rice, sugar, palm sugar, coffee, tea, and ginger put inside a closed cauldron.

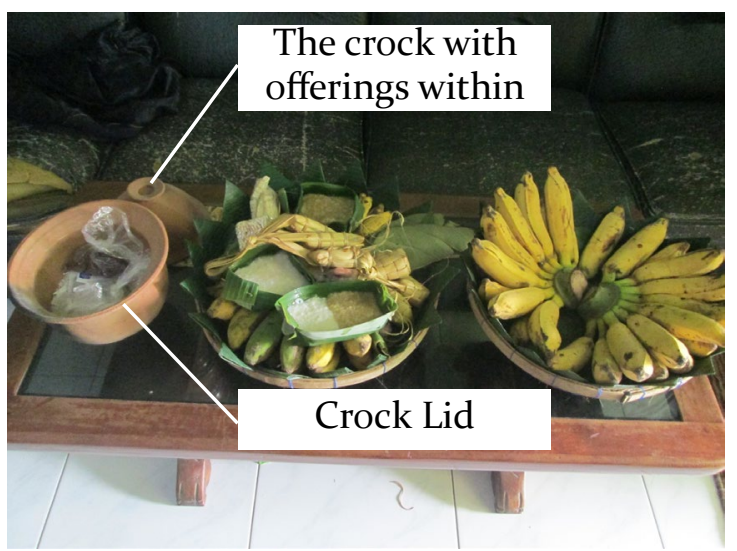

Figure 6. Covered crock for offerings. (Source: Researchers' Documentation, 2016).

Offerings were also placed in eight bowls that accommodated eight types of food, which are kunci daun kelor, gesek, cengkaruk, sambal gepeng, salt, buffalo meat, and sawan laut.

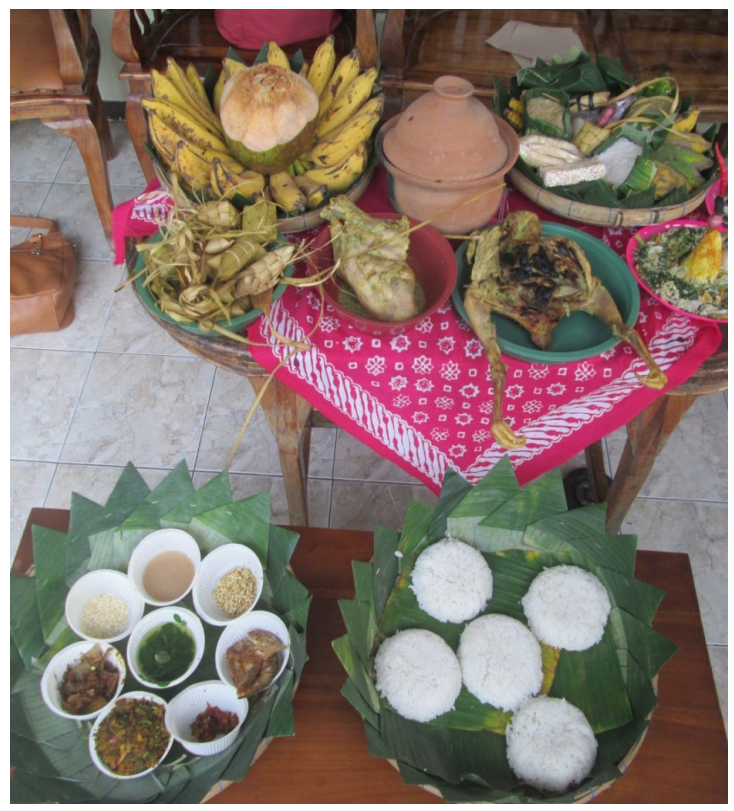

Figure 7. Small bowls as containers for vegetables, side dish, and boreh.

(Source: Researchers' Documenration, 2016; Sri Indrahti, et al, 2016:35).

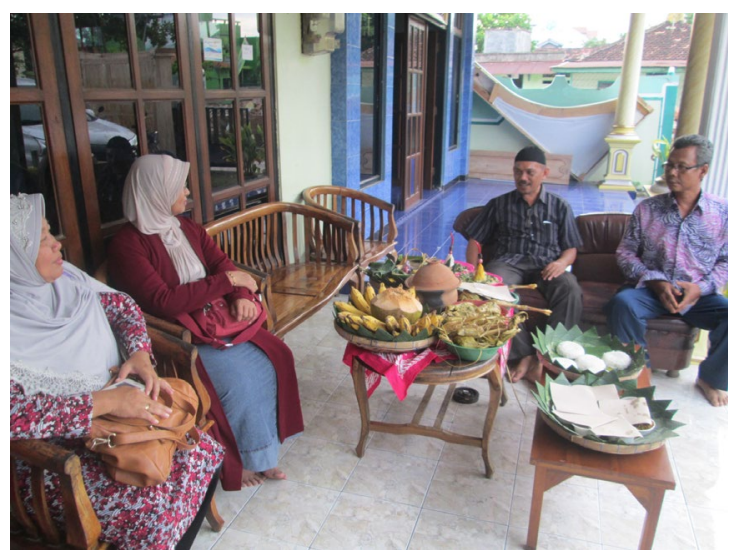

Figure 8. Plastic bowl and tray as containers for offerings.

(Source: Researchers' Documentation, 2016).

The main course of this festival is $k u$ pat, thus the festival is also often named bodo kupat. Two mountains of kupat with lepet as a complementary were the culinary served at Kartini Beach, and they were contested by the participants of lomban as seen in Figure 9. 

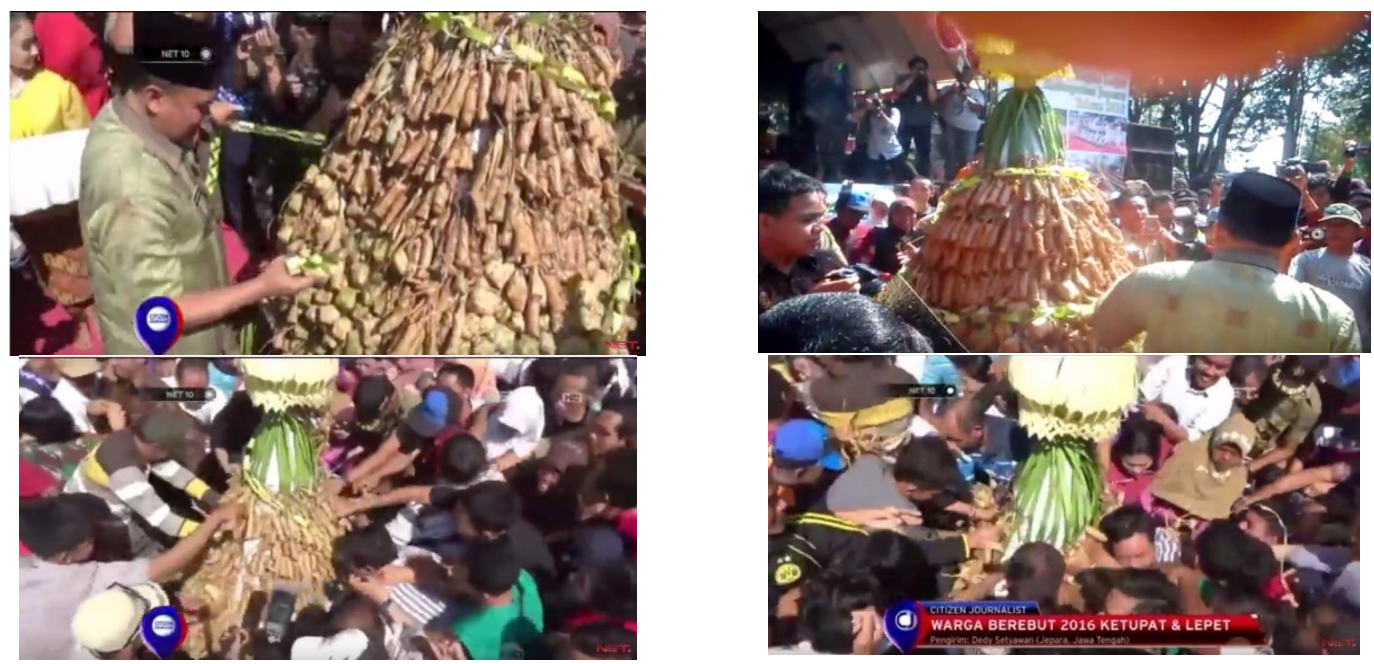

Figure 9. A mountain of kupat lepet, contested by people.

(Source: Indrahti, et al, 2016:36; https://www.youtube.com/watch?v=Q1qmBpSPmVQ downloaded on August $6^{\text {th }}$ 2016)

\section{A COMPARATIVE OF DUTCH EAST INDIES PERIOD AND RE- FORM PERIOD CULINARIES}

Based on the culinary studies of lomban festival in Jepara during Dutch East Indies period and Reform period, there are several differences connected to the various culinaries served. This could happen because of the descriptions from sources such as Tijdschrift voor Nederlandsch-Indië (1868) and dan Jawa: Geographisch, Ethnologisch, Historisch (1882), that state how lomban festival during Dutch East Indies period focused more on the the process of lomban activities. The symbolic meaning from the served culinary was not explained in detail. The culinary pictures that supported the visualization of the served culinary were also nowhere to be seen, for the use of natives cultural documentation was still rare.

Ketupat, Duck eggs, fruits of palm trees, and kolang-kaling were the culinary used during Dutch East Indies lomban festival. The side dishes, snacks, sherbets, and other foods were more widely used for the individual needs of visitors, and not a part of the lomban festival. Three culinary commodities (ketupat, duck eggs, and kolang-kaling) were used in the procession of throwing at each other during lomban festival. Still and all, ketupat was also eaten by lomban festival's participants. Not only as a syawalan activity, but lomban festival is also an activity that contains ritual activities and offerings. The offerings used were not food but related to pilgrimage activities to the tombs in Panjang Island and Kelor Island in the form of flowers and incense. Another ritual is a shower ritual in the morning as a symbol of luck before coming to lomban festival.

The culinary of lomban festival during the reform period is more complex due to its presence in every stages from pre, process, and post lomban festival. This culinary description can be done because it is supported by technology so that various culinary can be documented. Supporters of lomba festival also describe the symbolic meanings of various types of culinary. Even though kupat lepet is the dominant culinary, other culinary is still present in lomban festival. There are also offerings of yellow rice as well as various other rampe ubo like sea sawan (empon-empon and flowers are mashed by using traditional tools). According to the belief, Sea Sawan is a kind of boreh as a medicine for people affected by tuah or disturbed by the spirits of the sea, consisting of various Sea Sawan that can be purchased in traditional markets from empon-empon seller (Interview with Ms. Hj Iskarimah on 12 July 2016; Indrahti, et al, 2016: 34). 
The culinary include market snack (banana, apem, jadah, jenang, glutinous tape, diamond, apem, etc.), buffalo meat, nuk nukan rice, dhekem chicken, roast chicken, urap with 7 types of vegetables, vegetables bobor kelor, kupat, lepet, fruit, sugar, Javanese sugar, coffee, and tea, ginger, green degan, chicken dekem (ingkung), and so forth (Interview with Mrs. Hj. Iskarimah on July $12^{\text {th }}$ 2016; Indrahti, et al, 2016:34).

Kupat, within Javanese people, is defined as "ngaku lepat," or "admitting guilt. Lepet has never been absent in accompanying kupat in the servings for traditional ceremony. Just as kupat that is symbolized as the act of admitting guilt, lepet is also symbolized as the act of strengthening kinship due to the sticky nature of glutinous rice (Interview with Ms. Hj Iskarimah on 12 July 2016).

The meaning of kupat wrapped in janur (young coconut leaf) is "sejatine nur" (Javanese: True Light). The meaning of the rectangular shape of the parallelogram that resembles the human heart is "Heart filled with the True Light". Kupat is defined as "ngaku lepat, kula ingkang lepat" (Javanese: Admitting guilt is I, who have a mistake). Serving kupat with opor ayam (chicken braised in coconut milk) is symbolized as "nyuwun sepuro" (Javanese: Apologize). Hence, the meaning of it is admitting to having mistakes and preceding by apologizing (Alamsyah, 2013:23).

The tradition of larangan has been modified into a tradition that is not going against aqidah. Slaughtering buffalo for people's consumption has been executed in an Islamic way. Drifting buffalo head is a form of relationship between human and nature. Everyday, humans have a contact with the sea - thus giving foods to the fishes is needed. The drifting buffalo head is fought over by fishermen to be cooked at home. If no fishermen get buffaloes while seizing in the sea, then the buffalo head is the fish in the sea (Suara Merdeka, August 15, 2013: Alamsyah, 2013: 23).

Ingkung or ayam dhekem is a chicken that is cooked as a whole and can be defined as "enggala jangkung", which means "to hurry to kneel" or in other words to worship Allah completely. The Javanese also interpret ingkung with "enggalo manekung," that is to hurry to dhikr to Allah. Thus, ingkung, for Javanese people, is an invitation to hurry to worship completely to God by practicing prayer and dhikr.

While market snacks are interpreted as alms for the salvation of life, especially in the fields of spiritual and mental safety, or to survive from things that come from another dimension. Market snacks are also symbolized as a society, as well as prosperity. It is associated with how the market is seen; the market is where a variety of goods in the form of food, fruits, cigarettes, and so forth. Among market snacks, money in the form of "hundreds" in the Java language called "satus," which is a symbol of "sat" (asat) and "atus" (net) are also often found. Thus, the existence of that hundred of money symbolizes that man has been cleansed of sin (Endraswara, 2003: 199).

Banana, one comb or two combs, even one bunch are selected, but usually, a plantain is selected; either an ordinary plantain or a pulut plantain. Plantain has the meaning of the hope for the prayer to be a fair and virtuous person and someone who does not break promises to be answered. The pulut plantain means to be free from dangers that threaten.

\section{CONCLUSION}

The lomban festival in Jepara, whose existence has been present since the Dutch East Indies is an annual cultural event that combines ritual activities with recreational activities. In the Dutch East Indies period, the ritual activity of the lomban festival was seen with the pilgrimage to the grave of figures in Panjang Island and Kelor Island. Recreational activities are characterized by a procession of throwing diamonds, ducks, and duck eggs among the visitors of lomban festival. This recreation activity is also seen through the eating activity by the visitors who brought their own foods from home or they cook the foods themselves in the location where the lomban takes place. 
During the reform period, ritual activities are still done with pilgrimage activities. The culinary activities of the lomban festival during the reform period are more varied and well documented. This can be seen from the activities during the lomban process that is completed with various culinary and market snacks that are used during pre, process, and post lomban. From the comparison of the lomban festival during Dutch Indies period with the one from the reform period, the culinary that is still used is ketupat which includes kupat and lepet. Ketupat is also contested by the visitors as well as a symbol of togetherness in post-Lebaran or this syawalan activity.

\section{REFERENCES}

Alamsyah, 2013. "Budaya Syawalan atau Lomban di Jepara: Studi Komparasi Akhir Abad Ke-19 dan Tahun 2013." HUMANIKA, 18 (2).

Alamsyah, Indrahti, S., dan Maziyah, S., 2013. "Pemasaran Pariwisata Melalui Model Pembelajaran Pada Guide dengan Berbasis Peninggalan Budaya Lokal di Jepara." Laporan Hibah Bersaing Dikti Dana BOPTN, Lembaga Penelitian dan Pengabdian Kepada Masyarakat Universitas Diponegoro, Semarang.

Anwar, K., 2013. "Makna Kultural Dan Sosial-Ekonomi Tradisi Syawalan." Jurnal Walisongo, 21 (2).

Atmosudiro, S., 2004. "Khasanah Sumberdaya Arkeologi Indonesia: Peluang dan Kendala Pemanfaatannya." Pidato Pengukuhan Jabatan Guru Besar. Universitas Gadjah Mada, Yogyakarta.

Boikhutso, D.N., 2012. "Methods of Indigenous Knowledge Preservation in South Africa". Tesis. Tshwane University Of Technology, South Afrika. encore.tut.ac.za/iii/cpro/app?id... itemId $=1000655 \ldots$

Christomy, T. dan Yuwono, U., 2004. Semiotika Budaya. Pusat Penelitian Kemasyarakatan dan Budaya DRPM UI, Depok.

Endraswara, S., 2003. Mistik Kejawen Sinkretisme, Simbolisme dan Sufisme dalam Budaya Spiritual Jawa. Narasi, Yogyakarta.
Garraghan, S.J. G., 1957. A Guide to Historical Method. University Press, New York.

Geertz, C., 1976. Arts as Cultural System. Comparative Literature, MLN.

Geertz, C., 1992. Tafsir Kebudayaan. Diindonesiakan oleh Francisco Budi Hardiman. Penerbit Kanisius, Yogyakarta.

Indrahti, S. dan Maziyah, S., 2016. "Pemberdayaan Kuliner Berbasis Budaya Pada Masyarakat Kabupaten Jepara Untuk Pengembangan Produktivitas dalam Sektor Makanan Tradisional." Prosiding Seminar Antarbangsa: "Membangun Kapasitas Kreatif dan Kedasaran Budaya Menuju Keunggulan Peradaban Bangsa." Program Studi Magister dan Doktor. Program Pascasarjana Universitas Negeri Semarang, Semarang.

Indrahti, S., Maziyah, S., dan Alamsyah, 2017. "Ragam Kuliner Sesaji dalam Upacara Tradisi di Kabupaten Jepara." Jurnal Sejarah Citra Lekha, 2(1), pp. 61-74. doi:http://dx.doi.org/10.14710/jscl. v2i1.14547.

Koentjaraningrat, 2003. Pengantar Antropologi I. PT Rineka Cipta, Jakarta.

Poesponegoro, M.D., 1993. Sejarah Nasional Indonesia III. Balai Pustaka, Jakarta.

Sholikhin, M., 2010. Ritual dan Tradisi Islam Jawa. Penyunting: Lilih Prilian Ari Pranowo. Narasi, Yogyakarta.

Soekmono, 1993. Pengantar Sejarah Kebudayaan Indonesia 2. Penerbit Kanisius, Yogyakarta.

Soeratno, C., 2005. "Ekspresi Islam dalam SimbolSimbol Budaya di Indonesia." Dalam Triratnawati, Atik, dan Amini, Mutiah. 2005. Ekspresi Islam dalam Simbol-Simbol Budaya di Indonesia. Cetakan I. Lembaga Kebudayaan Pimpinan Pusat 'Aisyiyah bekerjasama dengan Adicita Karya Nusa, Yogyakarta.

Sulistyono, S.T., dkk., 2005. Penulisan Dan Pengkajian Upacara Tradisional Di Kabupaten Jepara. Departemen Pendidikan dan Kebudayaan Propinsi Jawa Tengah, Semarang.

Suliyati, T., Rochwulaningsih, Y., \& Utama, M., 2017. Interethnic Interaction Pattern in Karimunjawa Island. Komunitas: International Journal of Indonesian Society and Culture, 9(2), pp. 302-309. doi:http://dx.doi.org/10.15294/komunitas.v9i2.10719

TNI, 1868. Het Pada Loemban Feest Te Japara

Veth, P.J., 1882. Jawa: Geographisch, Ethnologisch, Historisch, derde deel.de Erven F. Bohn, Haarlem. 